\title{
The plant stimulant humic acid extracted from organic waste recycled by composting combined with liming and fertilization
}

\author{
Estimulante vegetal ácido húmico extraído de resíduo orgânico \\ reciclado por compostagem combinado com calagem e adubação
}

\author{
Marihus Altoé Baldotto ${ }^{1 *}$; Jayna Eloy da Rocha²; Francine Dias Paes Andrade ${ }^{2}$; \\ Marcos Paiva Del Giúdice ${ }^{1}$; Lílian Estrela Borges Baldotto ${ }^{1}$
}

\begin{abstract}
The disposal of organic waste can be an environmental problem; on the other hand, this waste can be the raw material for the production of biostimulants, among other recycling processes. The objective of this study was to recycle waste bovine manure and poultry litter through composting and isolate its humic acids in order to test their use, in the presence and absence of liming and fertilization, on corn plants as indicators. The experiment was conducted in a randomized block design with four replications. The experimental unit was a vase of $1 \mathrm{dm}^{3}$ filled with soil that received treatments generated by the combination of the factors under study: humic acids via seed, liming, and fertilization. After thirty days of the experiment, growth characteristics were measured to estimate the initial performance of the indicator corn plants in response to the treatments. The results showed that the combination of chemical fertilization with humic acids extracted from organic compounds increased the plants development. In conclusion, the use of biostimulants based on humic substances is positive and complementary to fertilizers used in agriculture, forming a superior combination. Such use is also recommended because it allows for the recycling of organic waste via composting, as well as the preparation of biostimulants for added technical, and potentially economic, value.
\end{abstract}

Key words: Recycling. Organic compost. Humic acids. Bioactivity.

\section{Resumo}

Os resíduos orgânicos podem ser um problema ambiental, no que diz respeito a sua destinação final, mas, por outro lado, matéria prima para a produção de bioestimulantes, entre outros processos de reciclagem. O objetivo do presente trabalho foi reciclar resíduos de esterco bovino e cama de aviário por meio da compostagem e isolar ácidos húmicos para serem testados usando plantas de milho como indicadores na presença e na ausência de calagem e adubação. O experimento foi conduzido no delineamento em blocos casualizados, com quatro repetições e a unidade experimental foi um vaso de $1 \mathrm{dm}^{3}$ preenchido com solo que receberam os tratamentos gerados pela combinação dos fatores em estudo ácidos húmicos via semente, calagem e adubação. Após 45 dias de experimento, foram medidas características de crescimento, para estimar o desempenho inicial das plantas indicadoras de milho em resposta aos tratamentos. Os resultados mostraram que a combinação de adubação química com ácidos húmicos extraídos de compostos orgânicos incrementou o desenvolvimento das plantas. Conclui-se que o uso dos bioestimulantes a base de substâncias húmicas é positivo e complementar à adubação usada na agricultura, formando uma combinação superior. Tal uso também é recomendado porque permite a reciclagem de resíduos orgânicos por meio da compostagem e o preparo de bioestimulante para agregarlhes valor técnico e potencialmente econômico.

Palavras-chave: Reciclagem. Composto orgânico. Ácidos húmicos. Bioatividade.

\footnotetext{
${ }^{1}$ Profs. Permanentes, Instituto de Ciências Agrárias, Universidade Federal de Viçosa, UFV, Florestal, MG, Brasil. E-mail: marihus@ufv.br; lilian.estrela@ufv.br; mgiudice@ufv.br

2 Discentes, Curso de Graduação em Tecnologia em Gestão Ambiental, UFV, Florestal, MG, Brasil. E-mail: jaynarocha@yahoo. com.br; fran_dias89@hotmail.com

* Author for correspondence
} 


\section{Introduction}

The most commonly found soils in Brazil are Latosols (EMBRAPA, 2013). Latosols are largely created through intense processes whereby their primary constituent materials are transformed, and silica and bases (e.g., $\mathrm{Ca}^{2+}, \mathrm{Mg}^{2+}, \mathrm{K}^{+}$) are removed or are in an advanced stage of weathering. The principal characteristics of Latosols are high acidity; activity of the aluminum ion, which is toxic to plant roots; and specific adsorption of phosphates, as well as a low capacity for retaining nutrients and water, which results in limited soil fertility (EMBRAPA, 2013). Minimizing the limitations of Latosols, with regard to their use for agriculture, can be achieved by increasing their organic carbon stock, which, in turn, improves their chemical, physical, and biological conditions through an increase in the generation of electric charges, i.e., their capacity for ion exchange. Moreover, this increases the retention of nutrients and water, as well as the complexation of toxic forms of aluminum and colloidal phosphate fixers. The increase in carbon stocks also improves the biological activity and aggregation and structuring of the soil, facilitating water and gas flow (BALDOTTO; BALDOTTO, 2014).

Organic fertilizer emerges as an opportunity to meet the growing need for the use and disposal of organic waste arising from human activities, as recommended by the National Policy on Solid Waste (Law $N^{\circ} 12.305 / 2010$; Federal Decree $N^{\circ}$ 7.004/2010; ABNT NBR 10004/2004). Among the alternatives for the disposal of organic waste, composting and the disposal of waste in soil have the greatest potential since the most common type of soil in Brazil requires such wastes to address its principal limitation and to increase its organic matter content (BALDOTTO; BALDOTTO, 2014).

The composting process recycles useable organic material from waste, thereby producing fertilizers and soil conditioners, reducing the demand for non-renewable products, and contributing to the agricultural and environmental sectors. However, recent studies have shown that compost can also be seen as a primary material for the derivation of bioactive substances, such as humic substances (BUSATO et al., 2012; AGUIAR et al., 2013; BALDOTTO; BALDOTTO, 2013; CANELLAS; OLIVARES, 2014). Since these organic compounds are in solid form and are not very water-soluble, the isolation of humic substances involves preparing them in liquid form, so they can be used on crops through application methods with a higher operating performance. Furthermore, isolation allows for the bioactive fractions of humus (the bioactivity of humic acids) to be concentrated, which generates better results with respect to plant productivity, and therefore, increases the value-added potential of the organic compound.

Humic acids promote plant growth by increasing metabolic activity in a way that is analogous to the effects of plant hormones. Humic acids increase nutrient absorption and cell division, which have direct effects on the quality and productivity of various crops (NARDI et al., 2002; FAÇANHA et al., 2002; CHEN et al., 2004; TEJADAE GONZALEZ, 2004; DELFINE et al., 2005; FERRARA; BRUNETTI, 2008; BUSATO et al., 2012; AGUIAR et al., 2013; BALDOTTO; BALDOTTO, 2013, 2014; CANELLAS; OLIVARES, 2014). Thus, humic acids have a stimulating action through the use of an interference mechanism on plant metabolism, resulting in effects on the soil as well as directly on the plant. Multiple soil effects are noted, including metal complexation, increased cation exchange capacity, moisture retention, etc. In the plant itself, humic acids influence the transport of ions, respiratory activity, chlorophyll content, synthesis of nucleic acids, and the activity of various enzymes, such as $\mathrm{H}^{+}$-ATPases of the plasma membrane (HAGER et al., 1991; NARDI et al., 2002; FAÇANHA et al., 2002; CHEN et al., 2004; TEJADA; GONZALEZ, 2004; DELFINE et al., 2005; FERRARA; BRUNETTI, 2008; BUSATO et al., 2012; AGUIAR et al., 2013; BALDOTTO; BALDOTTO, 2013; CANELLAS; OLIVARES, 2014). 
In this context, it is crucial to develop new technologies based on the recycling of organic waste, such as through composting, in order to isolate humic substances and take advantage of their ability to add economic value to these raw materials. These technologies can result in higher income generation, and with proper use of the final product, they can contribute to environmental preservation through decreased reliance on nonrenewable natural resources.

The objective of this study was to use organic waste from poultry litter and bovine manure as raw materials for preparing organic compounds and isolating their humic acids, which would then be tested on indicator plants such as maize, both with and without lime and fertilizer, with the aim of developing new technologies, adding economic value, and preserving the environment.

\section{Materials and Methods}

The experiment was conducted in the Laboratory of Chemistry and Soil Fertility, of the Universidade Federal de Viçosa, Campus Florestal, Minas Gerais, Brazil, during the year 2013. The factors under study were lime, fertilizer, and a biostimulant based on humic acids, as outlined in Table 1, resulting in eight treatments.

Table 1. List of treatments combining lime, fertilizer, and biostimulants (humic acids).

\begin{tabular}{|c|c|c|c|c|c|c|}
\hline \multicolumn{2}{|c|}{ Treatment } & \multicolumn{2}{|c|}{ Lime } & \multicolumn{2}{|c|}{ Fertilizer } & \multirow{2}{*}{$\begin{array}{c}\text { Biostimulant } \\
\text { mmol L }^{-1} \text { of } \mathrm{C}_{\mathrm{HA}}\end{array}$} \\
\hline $\mathrm{N}^{\circ}$ & Code $^{1}$ & $\mathrm{tha}^{-1}$ & $\mathrm{~g} \mathrm{dm}^{-3}$ & $\mathrm{~kg} \mathrm{ha}^{-1}$ & $\mathrm{~g} \mathrm{dm}^{-3}$ & \\
\hline 1 & $0 \mathrm{C} 0 \mathrm{~A} 0 \mathrm{~B}$ & 0.00 & 0.00 & 0.00 & 0.00 & 0 \\
\hline 2 & $1 \mathrm{C} 0 \mathrm{AOB}$ & 2.06 & 1.03 & 0.00 & 0.00 & 0 \\
\hline 3 & $0 \mathrm{C} 1 \mathrm{~A} 0 \mathrm{~B}$ & 0.00 & 0.00 & 643 & 12.86 & 0 \\
\hline 4 & $0 \mathrm{C} 0 \mathrm{~A} 1 \mathrm{~B}$ & 0.00 & 0.00 & 0.00 & 0.00 & 20 \\
\hline 5 & $1 \mathrm{C} 1 \mathrm{~A} 0 \mathrm{~B}$ & 2.06 & 1.03 & 643 & 12.86 & 0 \\
\hline 6 & 1C1A1B & 2.06 & 1.03 & 643 & 12.86 & 20 \\
\hline 7 & $1 \mathrm{C} 0 \mathrm{~A} 1 \mathrm{~B}$ & 2.06 & 1.03 & 0.00 & 0.00 & 20 \\
\hline 8 & $0 \mathrm{C} 1 \mathrm{~A} 1 \mathrm{~B}$ & 0.00 & 0.00 & 643 & 12.86 & 20 \\
\hline
\end{tabular}

${ }^{1}$ Code: $\mathrm{C}=$ lime; $\mathrm{A}=$ fertilizer; $\mathrm{B}=$ biostimulant (carbono as humic acids $-\mathrm{C}_{\mathrm{HA}}$ ). These codes will be used later in the results and discussion section in reference to the treatments.

The experimental unit consisted of $1 \mathrm{dm}^{3}$ pots filled with a layer of between 20 and $40 \mathrm{~cm}$ of a typical Dystrophic Red Latosol (EMBRAPA, 2013), previously described by Baldotto and Baldotto (2013). The experiment was conducted in a controlled environment, with a completely randomized design with four repetitions, totaling 32 experimental units, in which maize plants (AG1051) were grown as indicators. The experimental units were rotated and the temperature in the greenhouse was monitored.

The decision regarding which treatments would receive lime was determined as described by Alvarez and Ribeiro (1999), by the base saturation method. NPK fertilizer was used according to the recommendations of Alves et al. (1999). The treated soil and/or fertilizer were transferred to plastic containers, each of which received five seeds of maize (Table 1).

The waste used in composting for the isolation of humic acids to be tested as biostimulants came from the Cattle Sector of the Universidade Federal de Viçosa, and from Brasília farm, located in the Florestal municipality of Minas Gerais were isolated and characterized according to the recommendations of the International Humic Substances Society, as described in Baldotto and Baldotto (2014). The isolation of humic acids was performed by 
preparing a 1: $10(\mathrm{v} / \mathrm{v})$ extract from an organic compound prepared with poultry litter and bovine manure, in a solution of sodium hydroxide $\mathrm{NaOH}$ with a concentration of $0.1 \mathrm{~mol} \mathrm{~L}^{-1}$. After stirring for 4 hours, the extract was decanted, resulting in an insoluble precipitate called the humin fraction (which was not used in this study) and a supernatant solution containing humic and fulvic acids. The $\mathrm{pH}$ of the supernatant was adjusted to between 1 and 1.5, with $6 \mathrm{~mol} \mathrm{~L}^{-1} \mathrm{HCl}$, and the extract was separated, resulting in a supernatant solution containing fulvic acids (also discarded in this study), and a precipitate of humic acids, used as a biostimulant for plants.

The biostimulant was applied to seeds by

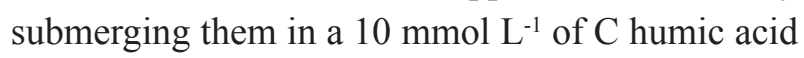
solution in plastic gerbox containers for 16 hours before planting. The humic acids consisted of 485 $\mathrm{g} \mathrm{kg}^{-1}$ of $\mathrm{C}$. The seeds that were not treated with biostimulants were soaked in distilled water so that similar water absorption conditions existed for all treatments. Humic acids were then applied as biostimulants to maize plants, with the presence and absence of lime and fertilizer and various combinations thereof (Table 1).

The containers were monitored daily (weighed) throughout the experiment and irrigation was used to keep the humidity between 80 and $100 \%$ of field capacity. Other management practices, such as weed control, plant protection treatments, lighting, and others, were controlled and kept constant for all treatments.

After planting, the development of the plants was monitored. Germination was observed to reach completion about 15 days after planting. After complete germination of all treatments, containers were thinned so that only two plants per container remained.
At the end of the experiment, 45 days after planting, results for the following variables were determined: plant height, leaf number, length of the largest leaf, width of the middle part of the largest leaf, base diameter, and the ratio of fresh mass of shoots to fresh mass of roots. The plants were then cut close to the ground and the fresh mass of shoots was weighed on a precision scale. Plant roots were isolated from the soil, crushed and washed thoroughly to determine their fresh mass. Both the aerial parts and the root system were packed in paper bags and placed in a forced ventilation oven at $60{ }^{\circ} \mathrm{C}$ for 72 hours, enough time for the plant material to dehydrate and reach a constant weight so that the dry mass of the shoots and roots could be determined. From these results, the ratio of the dry and fresh mass of the roots and shoots was obtained.

The results of the measurements were tabulated for statistical analysis using the SAEG 9.1 program (SAEG, 2016). A variance analysis of the data, averages, and variation coefficients and comparison tests between treatments (Tukey's test, at the 0.05 level of probability) were conducted.

\section{Results and Discussion}

Figure 1 (A-F) shows the performance results of the shoots of the indicator maize plants in response to the treatments.

We observed that the treatments containing fertilizer and biostimulant (0C1A1B), and also those that received lime and fertilizer $(1 \mathrm{C} 1 \mathrm{~A} 0 \mathrm{~B})$, were superior to the control treatment $(0 \mathrm{C} 0 \mathrm{~A} 0 \mathrm{~B})$ (Figure A). The other treatments did not perform differently from the control. 
Figure 1. Number of leaves (A), height (B) (unfilled bar), length (filled bar), and width of the largest leaf (C), base diameter (D), fresh mass (E), and dry mass (F) of shoots of maize plants in response to applications of lime, fertilizer, and biostimulant. Averages accompanied by the same lowercase letters are statistically similar to each other by Tukey's test at 0.05 probability.
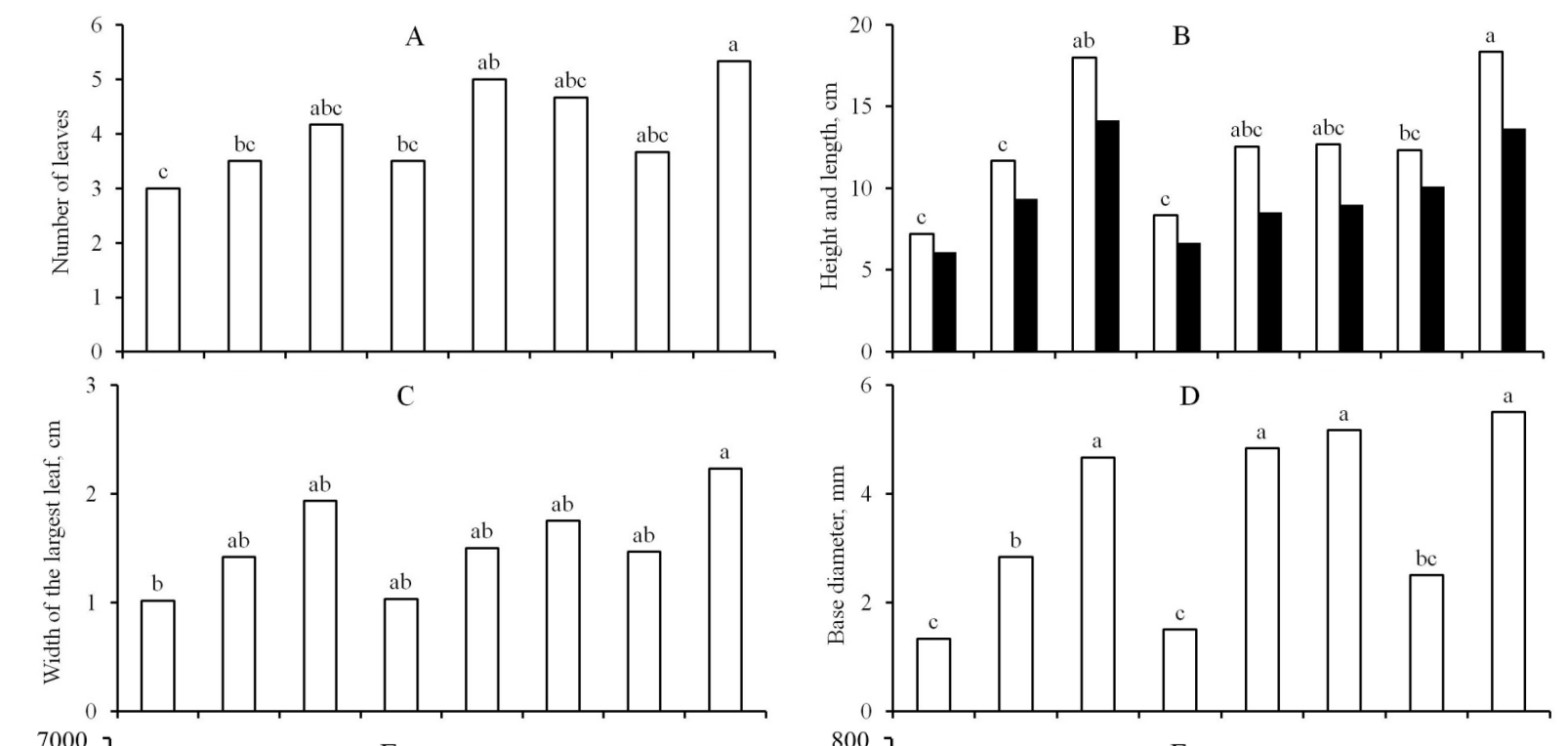

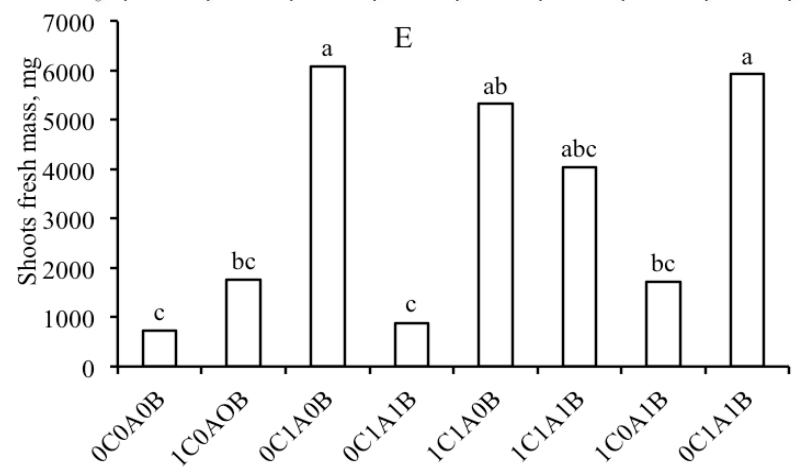

Treatments

The treatment that received only fertilizer (0C1A0B) showed the best performance, followed by the treatment with fertilizer and biostimulant (0C1A1B). Based on performance, the use of biostimulant did not result in a superior effect than in the use of fertilizer (Figure 1B and 1C).

From the analysis of data on the number, length, and width of the leaves, the greatest availability of leaf area to capture light energy and photosynthetic activity can be inferred. We observed that the

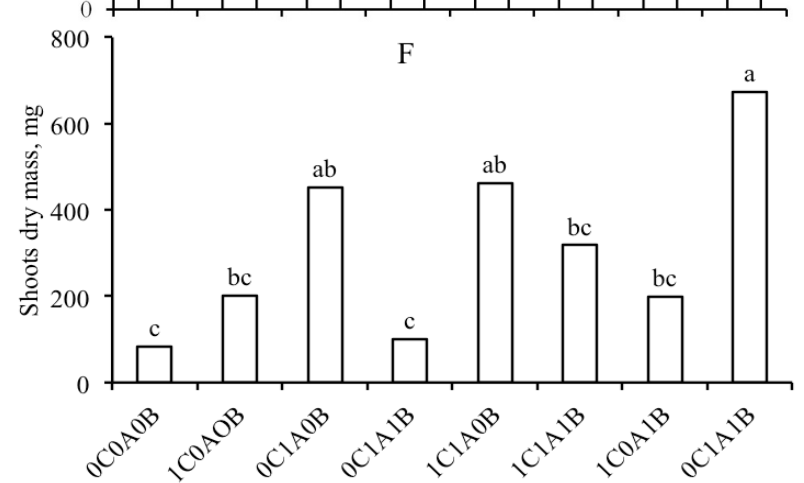

Treatments

treatment with fertilizer and biostimulant (0C1A1B) stood out in relation to the others. The treatment with biostimulant without added nutrients, and in the absence or presence of lime (0C0A1B and $1 \mathrm{C} 0 \mathrm{~A} 1 \mathrm{~B})$, showed averages similar to those of the control. This proves that the mechanism of action of humic acids involves an increased absorption of nutrients, and that in Latosols of low natural fertility, it does not help to stimulate plants without the addition of nutrients to the soil (BALDOTTO; 
BALDOTTO, 2014; CANELLAS; OLIVARES, 2014). In other words, this study deals with the application of humic acids according to the hormonal effect hypothesis (NARDI et al., 2002; CANELLAS et al., 2002), with humic acids applied to the propagation material in non-nutritional concentrations. The results of this study are in accordance with the hormonal effects hypothesis, and it is inferred that nutrients can be added as part of mineral, organic, or organic-mineral fertilizer, if in proper concentrations that optimize availability. Humic acids are thus used as growth regulators by various types of farmers (small farmers and agricultural businesses) and in different production systems (conventional and organic). The natural origin of these nutrients, having been derived from recycled waste by composting, allows for their potential use in certified organic agriculture, since synthetic growth regulators (analogous to plant hormones) have not been accepted by this consumer market (BALDOTTO; BALDOTTO, 2014).

Regarding the basal diameter of the plants, we observed that the treatments containing fertilizer and biostimulant (0C1A1B); lime, fertilizer, and biostimulant (1C1A1B); lime and fertilizer (1C1A0B); and fertilizer (0C1A0B); respectively, have larger diameters in relation to other treatments. The base diameters of plants have a positive relationship to crop development, i.e., the plants are performance indicators (AGUIAR et al., 2013).

Due to the availability of nutrients, the plants that developed best, and consequently had a greater amount of fresh mass, were those treated with fertilizer (0C1A0B) and with fertilizer and biostimulant (0C1A1B). The accumulation of fresh mass enabled the plant to improve its absorption of water, light and nutrients, creating a positive feedback cycle of growth, indicating that the plants were more productive in terms of accumulation of carbon and mineral nutrients, which is confirmed by the data on dry mass (Figure 1F).

This result is in line with studies carried out with maize (FAÇANHA et al., 2002), and other crops such as rice (TEJADA; GONZALEZ, 2004), wheat (DELFINE et al., 2005), grapes (FERRARA; BRUNETTI, 2008), gladiolus (BALDOTTO; BALDOTTO, 2013), and sugarcane (CANELLAS, OLIVARES, 2014). Humic acids increase the metabolism of plants. In other words, their main function, highlighted in the cited studies, is a hormonal type of function, in that they increase the absorption of nutrients and aid in cell division. It can be inferred that besides the biostimulant effect causing greater accumulation of dry mass, the functional groups present in humic acids have complexed the toxic $\mathrm{Al}^{3+}$ and thus, the effect of lime has not been expressed. Carboxylic functional groups (R-COOH) are the most abundant in the structure of humic substances. In soil, the complexation reactions of the aluminum ion occur as in the following equation (BALDOTTO; BALDOTTO, 2013):

$$
\begin{aligned}
& 3 \mathrm{R}-\mathrm{COOH}(\mathrm{s} / \mathrm{aq})+\mathrm{Al}^{3+}(\mathrm{aq})= \\
& \mathrm{R}-\mathrm{COOAl}(\mathrm{s} / \mathrm{aq})+3 \mathrm{H}^{+}(\mathrm{aq})
\end{aligned}
$$

As seen in the above equation 1, $3 \mathrm{~mol}$ of carboxylic groups (R-COOH) in the solid (s) or aqueous (aq) phase of humic substances can complex $1 \mathrm{~mol}$ of $\mathrm{Al}^{3+}$, inhibiting its toxic action to the roots. In general, humic substances present

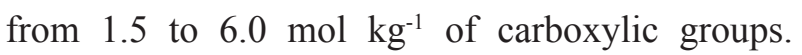
Thus, it appears that, given this complexation, the effect of lime was not significant for the treatments containing biostimulants. In other words, fertilizer combined only with humic acid resulted in a better performance of the indicator plants. Based on this complexing action of $\mathrm{Al}^{3+}$ by humic acids, it can be considered that their adoption for use will result in alleviating, at least in part, the costs of liming.

Comparing the results of the root/shoot ratio of the plants, based on both fresh mass and dry mass, we observed that the treatments with a higher biostimulant effect on the shoots tended to produce a smaller amount of roots (Figure 2). Other studies 
have reported the same trend (FAÇANHA et al., 2002; TEJADA; GONZALEZ, 2004; DELFINE et al., 2005; FERRARA; BRUNETTI, 2008; AGUIAR et al., 2013; BALDOTTO; BALDOTTO, 2013; CANELLAS; OLIVARES, 2014). The results presented in Figure 2 show that plants grown in optimal nutritional conditions allocate less energy to growing roots. In addition, from this point of view, we confirmed that treatments containing fertilizers and biostimulants were superior to other treatments. In addition to demonstrating fewer effects than in the treated plants, the maize plants from the control treatment need to adjust their morphology to compensate for the nutritional limitations, thus, the proportion of roots in relation to shoots increases. Since nutrient availability is a limiting factor in the soil, the control plants, even while exhibiting this behavior, do not grow properly. A negative cycle sets in: with less growth of shoots, there is a decrease in the uptake of light, and therefore, less photosynthesis and energy production. This fact demonstrates that it is advisable to follow proper nutritional management of the soil, with humic acids as biostimulants. However, because they have direct and indirect positive effects on the physiology of the plant, an increase in the performance of the indicator maize plants that received a combined application of fertilizer and humic acids, as compared to the isolated use of fertilizer, shows that the increased efficiency allows for better utilization by the plant of the fertilizer itself. This fact indicates that the calibration of nutrient doses should indicate the economic optimization of the potential combination of fertilizer and humic acids (BALDOTTO; BALDOTTO, 2014).

Figure 2. Fresh mass (A) and dry mass (B) of the roots and the ratio between fresh mass (C) and dry mass (D) of the roots and shoots of maize plants used as indicators in response to applications of lime, fertilizer, and biostimulant. Averages accompanied by the same lowercase letters are statistically similar by Tukey's test at 0.05 probability.
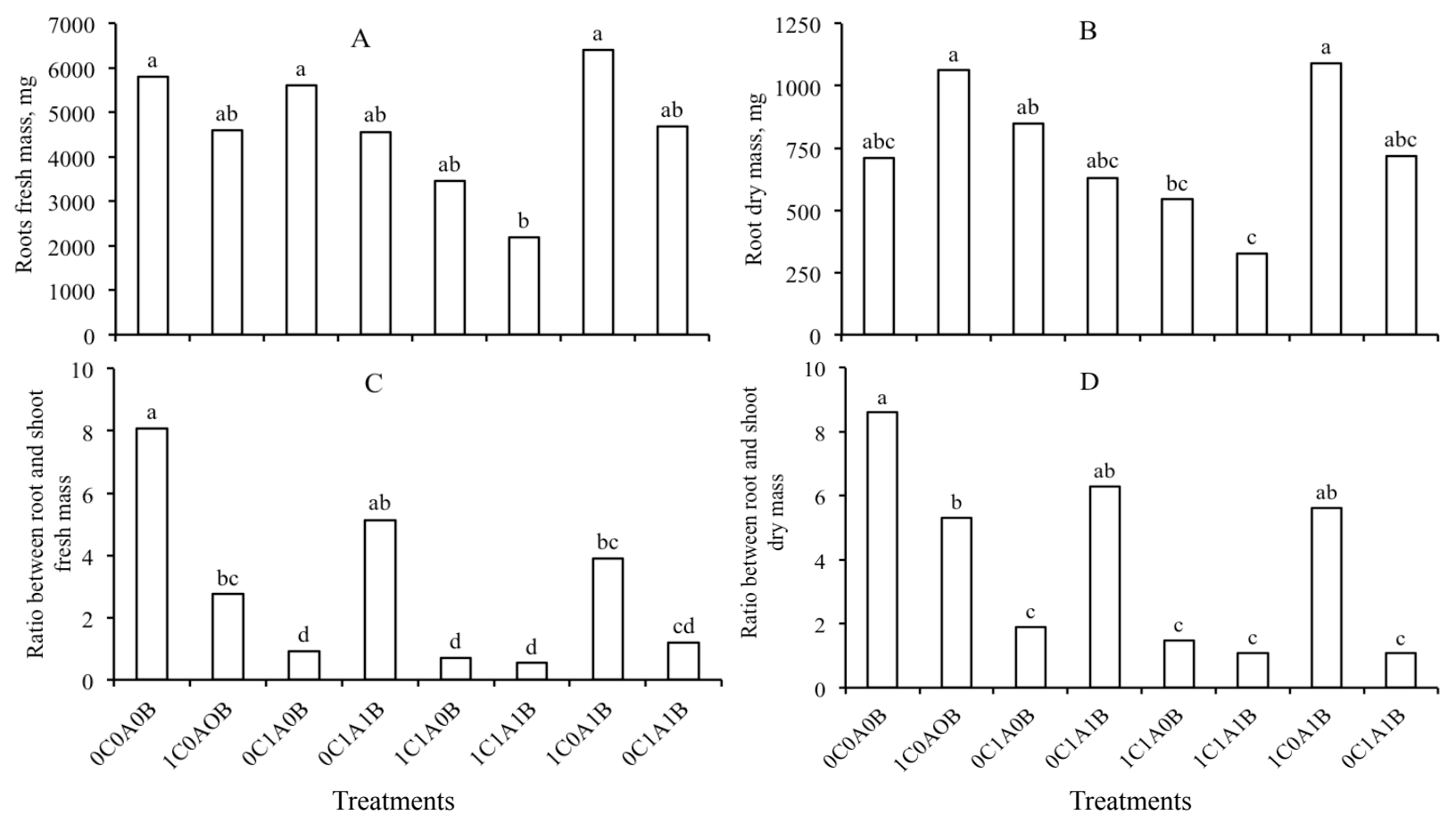
Finally, the superiority of the treatment containing biostimulants in addition to fertilizer, as exhibited in the initial development as well as the accumulation of dry mass in the indicator plants in this study, also confirms the hypothesis that new technologies can be developed based on recycled organic waste. The ease of application of the biostimulants in liquid form, and the significant reduction of the quantities of humus to be applied also make the technology economically attractive. The estimated costs for the use of humic acids arise from the need for workers to handle the extraction and application, since the amounts of compound and reagents are relatively low and are prepared by hand. For economic analysis, the cost can be considered to be equivalent to two days of labor by a farm worker, whose training for extracting humic acids would be simple and would require no additional investment in the existing family farming unit. Moreover, the preparation of biostimulants in liquid form can provide an optimal effect as compared to applying the compound in solid form since, on average, less than $5 \%$ of the organic compound would be soluble (BALDOTTO; BALDOTTO, 2014). Therefore, the data allow us to infer that, among the treatments tested in this study, the recommended strategy would be to combine the application of humic acids as biostimulants with the addition of fertilizer, increasing their efficiency and resulting in plants with higher performance.

\section{Conclusions}

1. Treatments with lime, fertilizer, and humic acids extracted from organic compounds showed a superior effect than in the control treatment, indicating that growing crops on Latosols without proper management is not economical and is environmentally unfavorable.

2. The biostimulant effect of humic acids was higher than in the control. The effect was increased with the addition of fertilizer, but it did not increase with the addition of lime.
3. The use of biostimulants based on humic substances is positive and complementary to fertilizers used in agriculture, forming a superior combination. Such use is also recommended because it allows for the recycling of organic waste via composting, as well as the preparation of biostimulants for added technical, and potentially economic, value.

\section{Acknowledgements}

The authors thank CNPq (Universal Process Notice $\left.2014 \mathrm{~N}^{\circ} 470192 / 2013-5\right)$ at FAPEMIG (Universal Process Notice 2014 No APQ 00450/13) for the funding that was awarded to projects that initiated this study.

\section{References}

AGUIAR, N. O.; OLIVARES, F. L.; NOVOTNY, E. H.; DOBBSS, L. B.; SANTOS-JÚNIOR, L. G.; CHAGAS, J. G.; FAÇANHA, A. R.; CANELLAS, L. P. Bioactivity of humic acids isolated from vermicomposts at different maturation stages. Plant and Soil, The Hague, v. 36, n. 2, p. 161-174, 2013.

ALVAREZ, V. V. H.; RIBEIRO, A. C. Calagem. In: RIBEIRO, A. C.; GUIMARÃES, P. T. G.; ALVAREZ, V. V. H. (Ed.). Recomendação para o uso de corretivos e fertilizantes em Minas Gerais. $5^{\text {a }}$ Aproximação. 5. ed. Viçosa, MG: Comissão de Fertilidade do Solo do Estado de Minas Gerais, 1999. p. 52-69.

ALVES, V. M. C.; VASCONCELOS, C. A.; FREIRE, F. M.; PITTA, G. V. E.; FRANÇA, G. E.; FILHO, A. R.; ARAÚJO, J. M.; VIEIRA, J. R.; LOUREIRO, J. E. Milho. In: RIBEIRO, A. C.; GUIMARÃE, P. T. G.; ALVAREZ, V. V. H. (Ed.). Recomendação para o uso de corretivos e fertilizantes em Minas Gerais. $5^{\text {a }}$ Aproximação. 5. ed. Viçosa, MG: Comissão de Fertilidade do Solo do Estado de Minas Gerais, 1999. p. 314-316.

BAldotto, M. A.; BALdotto, L. E. B. Ácidos húmicos. Revista Ceres, Viçosa, MG, v. 61, n. 7, p. 856881, 2014.

Gladiolus development in response to bulb treatment with different concentration of humic acids. Revista Ceres, Viçosa, MG, v. 60, n. 1, p. 138-142, 2013. 
BUSATO, J. G.; LEÃO, T. P.; BALDOTTO, M. A.; CANELLAS, L. P. Organic matter quality and dynamics in tropical soils amended with sugar industry residue. Revista Brasileira de Ciência do Solo, Viçosa, MG, v. 36, n. 4, p. 1179-1188, 2012.

CANELlAS, L. P.; OLIVARES, F. L. Physiological responses to humic substances as plant growth promoter. Chemical and Biological Technologies in Agriculture, Naples, v. 1, n. 1, p. 3-14, 2014.

CANELLAS, L. P.; OLIVARES, F. L.; OKOROKOVAFACANHA, A. L.; FACANHA, A. R. Humic acids isolated from earthworm compost enhance root elongation, lateral root emergence, and plasma membrane H-ATPase activity in maize roots. Plant Physiology, Rockville, v. 130, n. 4, p. 1951-1957, 2002.

CHEN, Y.; CLAPP, C. E.; MAGEN, H. Mechanisms of plant growth stimulation by humic substances: The role of organo-iron complexes. Soil Science and Plant Nutrition, Tokyo, v. 50, n. 7, p. 1089-1095, 2004.

DELFINE， S.; TOGNETTI，R.; DESIDERIO, E.; ALVINO, A. Effects of foliar application of $\mathrm{N}$ and humic acids on growth and yield of durum wheat. Agronomy for Sustainable Development, Netherlands, v. 25, n. 2, p. 183-191, 2005.

EMPRESA BRASILEIRA DE PESQUISA AGROPECUÁRIA - EMBRAPA. Centro Nacional de Pesquisa em Solos. Sistema Brasileiro de Classificação de Solos. 3. ed. Rio de Janeiro: Embrapa Produção de Informação, 2013. 353 p.
FAÇANHA, A. R.; FAÇANHA, A. L. O.; OLIVARES, F. L.; GURIDI, F.; SANTOS, G. D. A.; VELLOSO, A. C. X.; CANELLAS, L. P. Bioatividade de ácidos húmicos: efeitos sobre o desenvolvimento radicular e sobre a bomba de prótons da membrana plasmática. Pesquisa Agropecuária Brasileira, Brasília, v. 37, n. 9, p. 13011310, 2002.

FERRARA, G.; BRUNETTI, G. Influence of foliar applications of humic acids on yield and fruit quality of table grape cv. Italia. Journal International des Sciences de la Vigne et du Vin, Bordeaux, v. 42, n. 1, p. 79-87, 2008.

HAGER, A.; DEBUS, G.; EDEL, H. G.; STRANSKY, H.; SERRANO, R. Auxin induces exocytosis and rapid synthesis of a high-turnover pool of plasma-membrane $\mathrm{H}^{+}$ATPase. Planta, Berlin, v. 185, n. 6, p. 527-537, 1991.

NARDI, S.; PIZZEGHELLO, D.; MUSCOLO, A.; VIANELLO,A. Physiological effects of humic substances in higher plants. Soil Biology and Biochemistry, Oxford, v. 34 , n. 7, p. 1527-1537, 2002.

SISTEMA PARA ANÁLISES ESTATÍSTICAS - SAEG. Análises estatísticas. Versão 9.1: Fundação Arthur Bernardes. Viçosa, MG: Universidade Federal de Viçosa, 2016. Disponível em: <http://www.ufv.br/saeg/>. Acesso em: 15 jun. 2016.

TEJADA, M.; GONZALEZ, J. L. Effect of foliar application of a byproduct of the two-step olive oil mill process on rice yield. European Journal of Agronomy, Copenhagen, v. 21, n. 1, p. 31-40, 2004. 
